\title{
SARS-CoV-2 Infection in the Central and Peripheral Nervous System-Associated Morbidities and Their Potential Mechanism
}

\author{
Mohan Kumar Muthu Karuppan ${ }^{1} \cdot$ Dinesh Devadoss $^{1} \cdot$ Madhavan Nair $^{1} \cdot$ Hitendra S. Chand ${ }^{1}$. \\ Madepalli K. Lakshmana ${ }^{1}$ (D)
}

Received: 1 July 2020 / Accepted: 2 December 2020 / Published online: 13 January 2021

(C) The Author(s), under exclusive licence to Springer Science+Business Media, LLC part of Springer Nature 2021

\begin{abstract}
The recent outbreak of SARS-CoV-2 infections that causes coronavirus-induced disease of 2019 (COVID-19) is the defining and unprecedented global health crisis of our time in both the scale and magnitude. Although the respiratory tract is the primary target of SARS-CoV-2, accumulating evidence suggests that the virus may also invade both the central nervous system (CNS) and the peripheral nervous system (PNS) leading to numerous neurological issues including some serious complications such as seizures, encephalitis, and loss of consciousness. Here, we present a comprehensive review of the currently known role of SARS-CoV-2 and identify all the neurological problems reported among the COVID-19 case reports throughout the world. The virus might gain entry into the CNS either through the trans-synaptic route via the olfactory neurons or through the damaged endothelium in the brain microvasculature using the ACE2 receptor potentiated by neuropilin-1 (NRP-1). The most critical of all symptoms appear to be the spontaneous loss of breathing in some COVID-19 patients. This might be indicative of a dysfunction within the cardiopulmonary regulatory centers in the brainstem. These pioneering studies, thus, lay a strong foundation for more in-depth basic and clinical research required to confirm the role of SARS-CoV-2 infection in neurodegeneration of critical brain regulatory centers.
\end{abstract}

Keywords ACE1 - ACE2 - Brain · COVID-19 - Coronavirus · Headache $\cdot$ Loss of consciousness $\cdot$ Loss of smell $\cdot$ Loss of taste Neuropilin- $1 \cdot$ Nervous system $\cdot$ SARS-CoV-2 $\cdot$ Seizures $\cdot$ Stroke

$\begin{array}{ll}\text { Abbreviations } & \\ \text { ACE2 } & \text { Angiotensin-converting enzyme 2 } \\ \text { ARDS } & \text { Acute respiratory distress syndrome } \\ \text { BBB } & \text { Blood-brain barrier } \\ \text { BNB } & \text { Blood-nerve barrier } \\ \text { BSCB } & \text { Blood-spinal cord barriers } \\ \text { CMAP } & \text { Compound muscle action potential } \\ \text { CNS } & \text { Central nervous system } \\ \text { CTSL } & \text { Cathepsin L } \\ \text { GBS } & \text { Guillain-Barré syndrome } \\ \text { HIF-1 } \alpha & \text { Hypoxia-inducible factor 1-alpha } \\ \text { COVID-19 } & \text { Coronavirus-induced disease of 2019 } \\ \text { HCoV } & \text { Human coronaviruses } \\ \text { IL } & \text { Interleukin } \\ \text { MAFLD } & \text { Metabolic-associated fatty liver disease }\end{array}$

Madepalli K. Lakshmana

mlakshma@fiu.edu

Department of Immunology and Nano-Medicine, Alzheimer's Disease Research Unit, Herbert Wertheim College of Medicine, Florida International University, 11200 SW 8th Street, Miami, FL 33199, USA

\begin{tabular}{|c|c|}
\hline MERS-CoV & $\begin{array}{l}\text { Middle East Respiratory } \\
\text { Syndrome Coronavirus }\end{array}$ \\
\hline NRP-1 & Neuropilin-1 \\
\hline PAR-1 & Proteinase-activated receptor -1 \\
\hline PNS & Peripheral nervous system \\
\hline SARS-CoV & $\begin{array}{l}\text { Severe acute respiratory } \\
\text { syndrome coronavirus }\end{array}$ \\
\hline SAP & Sensory nerve action potential \\
\hline SASP & $\begin{array}{l}\text { Senescence-associated secretory } \\
\text { phenotype }\end{array}$ \\
\hline SARS-CoV-2 & $\begin{array}{l}\text { Severe acute respiratory } \\
\text { syndrome coronavirus } 2\end{array}$ \\
\hline+ ssRNA & Positive single-stranded RNA \\
\hline STD’s & Smell and/or taste disorders \\
\hline TMPRSS2 & Transmembrane protease serine 2 \\
\hline
\end{tabular}

\section{Background}

Respiratory infections caused by four human coronaviruses ( $\mathrm{HCoV}$ ) including $\mathrm{HCoV}-\mathrm{OC} 43, \mathrm{HCoV}-229 \mathrm{E}, \mathrm{HCoV}-$ NL63, and HCoVHKU1 were not fatal, while the infections 
caused by Severe Acute Respiratory Syndrome Coronavirus (SARS-CoV) and the Middle East Respiratory Syndrome Coronavirus (MERS-CoV) were fatal. Both SARS-CoV and MERS-CoV are primarily zoonotic viruses. Till date, there is no specific treatment for the coronaviruses [1]. The novel and more contagious strain of current coronavirus which is highly transmissible in humans as initially reported from Wuhan, the capital of Hubei, China, during December 2019. China reported this cluster of pneumonia cases in Wuhan during the last week of December 2019 (31-Dec2019 as per the WHO website, https://www.who.int/newsroom/detail/08-04-2020-who-timeline\%2D\%2D-COVID19) and WHO published its first coronavirus outbreak during the first week of January 2020 with no reported deaths. Accordingly, the WHO issued guidelines to all countries. Thailand recorded the first coronavirus case from outside China during the second week of January 2020. During the early stages, this coronavirus was named "the new coronavirus, 2019-nCoV" and later on in February 2020 , this virus strain's official taxonomic designation was replaced with "severe acute respiratory syndrome coronavirus 2" (SARS-CoV-2). Then, the WHO officially renamed the disease caused by SARS-CoV-2 as COVID19. Due to alarming levels of spread and severity, the WHO made an assessment and characterized the COVID19 as a global pandemic on March 11, 2020, [2] (https:// www.who.int/emergencies/diseases/novel-coronavirus2019). COVID-19 has now spread to 235 countries throughout the world, infecting nearly 57 million people and has resulted in 1,368,000 confirmed deaths worldwide. In the USA alone, nearly $11,650,817$ people were confirmed to have COVID-19 and 251,715 people died (as on 11/21/ 2020) (Ref: WHO, https://covid19.who.int/table and CDC website; https://www.cdc.gov/coronavirus/2019-ncov/ cases-updates/cases-in-us.html). Common symptoms reported in a person infected with COVID-19 include respiratory deficiencies, fever, cough, shortness of breath, and loss of smell and taste. Severe infection may cause pneumonia, severe acute respiratory syndrome, kidney failure, neurological diseases, and ultimately leading to death [3].

\section{ACE2 Expression Distribution}

Structural and functional analysis indicates that the spike protein of SARS-CoV-2 binds to ACE2 protein [4-6]. Brain cells were reported to express ACE2 virtually throughout the brain as a transmembrane protein and specifically in the areas controlling central blood pressure [7, 8]. Data analysis also suggested that there were no significant differences in ACE2 protein expression levels in males versus females or young versus old or even among different ethnic groups [9]. However, the observed higher vulnerability of elderly people especially males might be due to dysregulated host immune response to coronavirus infection. The expression pattern of ACE2 in brain regions is consistent with the reported symptoms such as confusion, headache, seizures, increased brain volume, diarrhea, nausea, and vomiting [10-12]. However, it should be noted that negative results with no observed ACE2 mRNA in the human brain have also been reported $[12,13]$. There is also strong evidence to suggest that SARS-CoV-2 coronavirus may gain entry to the body through the tongue and oral cavity [14]. To date, the ACE2 distribution is based mostly on mRNA data, which does not reflect the true functional protein distribution including any posttranslational modifications, and therefore, more immunohistochemical characterization studies especially at cell type level are urgently required.

\section{Neuropilin-1 (NRP-1) and SARS-CoV-2 Entry}

While ACE2 is the main receptor to which the SARSCoV-2 spike protein binds and enters the cells, the spike protein is primed by the TMPRSS2 for viral entry. More recently, it was also discovered that neuropilin-1 (NRP1) significantly potentiates viral infectivity especially into olfactory epithelial cells in the nasal cavity, a role validated using NRP1 antibody [15-17]. It was also found that NRP1 requires a furin-cleaved substrate to aid in the virus entry and NRP1 mRNA expression is elevated in SARSCoV-2-infected cells from COVID-19 patients [15]. Interestingly, while ACE2 was expressed at low levels in both human lung tissue and olfactory epithelium, the expression of NRP1 was found to be abundant in these tissues [15]. Due to the lack of protein kinase domain, NRP1 is known to act primarily as a co-receptor for several ligands to modulate angiogenesis, cell proliferation, and axon guidance $[18,19]$. Indeed, the further recent demonstration of NRP1 expression in the olfactory tubercles and paraolfactory gyri of the human brain [20] further supports the role of NRP1 in SARS-CoV-2 entry into olfactory epithelial cells. This could clearly explain the loss of olfactory function in COVID-19 patients. Further, spike protein has been shown to block vascular endothelial growth factor-A (VEGF-A)/NRP1 signaling leading to reduced pain perception [21], which may underlie increased disease transmission in asymptomatic COVID-19-infected individuals. In silico efforts followed by validation in cells have already identified several inhibitors of the VEGF-A/NRP-1 signaling [22] which can now be tested in inhibiting SARS-CoV-2 virus entry. Thus, NRP1 represents a novel ACE2 potentiating factor to promote interaction of the virus with ACE2 for cellular entry and provides an additional target to develop blockers of virus entry. 


\section{Risk Factors for COVID-19 Severity and Mortality}

\section{Aging and Coronavirus}

COVID-19 affects a broad age group of subjects ranging from infants to the elderly population. One of the earliest communications from Wuhan, China, reported that during early January 2020, 6 children (< 16 years old) were diagnosed with COVID-19 [23]. Available data suggest that older individuals, in particular, are at higher risk for COVID-19, especially people with pre-existing multimorbidity [24, 25]. As per recent reports, it affects community-dwelling elderly including those residing in the nursing homes and in particular those in assisted living facilities are at higher risk [26, 27]. The fatality rate for COVID-19 in the USA increases with age from 3 to $5 \%$ between 65 and 74 years, 4 to $11 \%$ between 75 and 84 years, and 10 to $27 \%$ above 85 years. Among COVID-19 patients over 65 years, there were $45 \%$ hospitalizations, $53 \%$ of intensive care unit (ICU) admissions, and $80 \%$ of death [28] (https://www.cdc.gov/mmwr/volumes/69/wr/mm6912e2. htm). In China, the fatality rate is $0.1 \%$ among children and $14.8 \%$ in older individuals [29]. One possible reason for the risk in the old age population could be due to the deteriorating immune system that mounts a feeble immune response [30]. Children less than 18 years of age are less affected $(1.7 \%)$ compared to adults [31] (CDC: https://www.cdc.gov/mmwr/ volumes/69/wr/mm6914e4.htm). More recent reports suggest that vertical transmission from pregnant mother to infants is also possible [32] with demonstrated viral load in infant tissues [33]. Sadly in Texas, USA, a 6-week-old infant was reported to have died from COVID-19 as per the county public health district reports, while another 6-week-old infant recovered from COVID-19 at the Downey Medical Center in California, USA.

Structural studies predict that COVID-19 spike glycoproteins also directly interact with host cell CD26, a known surface marker of senescent cells [34]. One of the hypotheses is that the COVID-19 infection significantly increases the mortality in patients with advanced chronological age because these patients have a large number of senescent lung cells. These senescent lung cells may be the target for coronavirus infection. Senescent cells showed an increased propensity for enhanced protein synthesis, which is required to produce senescence-associated secretory phenotype (SASP and inflammatory cytokines including IL-6) rendering these cells as an ideal host target for efficient viral replication [35].

\section{Cardiovascular System and Coronavirus Infection}

COVID-19 patients with a history of hypertension are more vulnerable to death with increased troponin levels which is a standard cardiac injury biomarker [36]. The mortality rate of
COVID-19 patients with cardiac injury is higher $(51.2 \%)$ compared to non-cardiac injury patients (4.5\%) [37]. Patients with pre-existing cardiovascular disease such as hypertension and related conditions experience disproportionately worse outcomes with SARS-CoV-2 infection. This can lead to the development of cardiovascular complications such as heart failure, myocarditis, pericarditis, vasculitis, and cardiac arrhythmias. Dynamic increase of highly sensitive troponin levels and natriuretic peptides increase the arrhythmias and increase the risk of requiring ventilation and mortality rate $[38,39]$. There is now clear evidence of the presence of SARS-CoV-2 in the cardiomyocytes as demonstrated recently in all six patients examined following postmortem in Italy [40]. The viral particles of 70-100 $\mathrm{nm}$ in diameter consistent with the size and shape of SARS-CoV-2 were also demonstrated by electron microscopy even in the cardiomyocytes of a child [41].

\section{Endothelial Cell Damage}

SARS-CoV-2 infects the host system using the ACE2 receptor, which is also highly expressed in endothelial cells [42]. SARS-CoV-2 is reported to directly infect engineered human blood vessel organoids in vitro [43], indicating that endothelial cells can get infected by a coronavirus. Postmortem analysis of COVID-19 patient of a 71-year male reported with viral inclusion structures with apoptotic bodies in endothelial cells by electron microscopy analysis [44]. Results from another autopsy study showed lung with diffuse alveolar damage and perivascular $\mathrm{T}$ cell infiltration in COVID-19 associated respiratory failure. These lungs were also reported to have distinctive vascular features consisting of severe endothelial injury associated with the presence of the intracellular virus and disrupted cell membrane and the histology indicated thrombosis with microangiopathy. Lungs from COVID-19 patients also were reported to show new vessel growth through the mechanism of intussusceptive angiogenesis [45]. More recent data suggest that micro thrombosis is a major complication in COVID-19 patients likely due to progressive endothelial cell damage which might account for multi-organ failure $[46,47]$.

\section{Diabetes Mellitus and Obesity}

COVID-19 patients with poor outcomes presented with established and irreversible metabolic dysfunctions. Diabetes mellitus is a highly prevalent metabolic disorder that is accompanied by other comorbid conditions like hypertension, obesity, and low cytosolic $\mathrm{pH}$. Due to low cytosolic $\mathrm{pH}$, the viral load may increase and exacerbate the infection [48]. Another report indicated that diabetes mellitus is the second most frequent comorbidity admitted with COVID-19 cases and 
diabetic patients are at higher risk of ICU admission and show a higher mortality rate [49].

In the case of obesity, the visceral adipose tissue is reported to secrete IL-6 and these levels were found to be retrospectively increased in COVID-19 non-survivors [50]. Treatment with Tocilizumab, a monoclonal antibody inhibitor of IL-6 receptor, reported showing improvement in respiratory function in COVID-19-related acute respiratory distress syndrome (ARDS) [51]. Another recent study in China reported that obesity in metabolic-associated fatty liver disease (MAFLD) has $\sim 6$-fold increased risk for COVID-19 in the age group of 18 to 75 [52]. These multiple pieces of evidence suggest that both diabetes and obesity increase the risk of developing severe COVID-19.

\section{Liver and Kidney Injury}

Medications prescribed to infected patients may cause liver damage due to adverse drug reactions and systemic inflammation, indicating that liver function should be monitored and evaluated during the treatment period [53]. Other pathological findings in the liver include sinusoidal lymphocytic infiltrations and sinusoidal dilatations as well as mild steatosis and multifocal hepatic necrosis [54]. Another group reported microvascular steatosis, mild lobular, and portal activity in COVID-19 patients suggesting that the liver injury could have been caused by a viral infection or drug interactions. Therefore, patients with pre-existing liver injury should be monitored during antiviral and anti-inflammatory drug treatment [55]. The development of acute kidney injury is also high in infected patients and is associated with increased inhospital mortality [56]. Mechanisms of kidney injury could be due to acute tubular necrosis, the direct cytotoxic effect of the virus itself, or immune-mediated damage [23].

Also, Zhang et al. reported an increased incidence of hepatic abnormalities after infection with SARS-CoV-2, and during disease, this could be due to the direct effect of SARS-CoV-2 on the liver or side effect of the medications used by patients [57]. Liver biopsy of COVID-19 patients was reported to have steatosis and liver injury [58]. Acute renal injury is also reported to increase during coronavirus infection. This could be due to inflammation induced by disease or infection in the kidneys. Most of the medications are metabolized by the liver and excreted by the kidney, so these two vital organs need to be considered before treatment for coronavirus infection. Patients with acute renal injury are reported with a higher mortality rate compared to other patients [59].

\section{Central Nervous System and Associated Comorbidities}

In general, viral infections are known to cause severe damage to the structure and function of the nervous system, resulting in encephalitis, toxic encephalopathy, and acute demyelinating lesions $[60,61]$. Encephalitis refers to the inflammation of the brain parenchyma caused by pathogens that may result in neuronal damage and nerve tissue lesions. Encephalitis is characterized by acute onset and common symptoms like headache, fever, vomiting, confusion, convulsions, and consciousness issues [62]. SARS-CoV-2 infection was also reported to cause viral encephalitis and the presence of viral genome was confirmed in the cerebrospinal fluid (CSF) [63, 64]. Additionally, autopsy reports indicated edema of the brain tissue and partial neuronal degeneration in deceased patients [65]. Acute toxic encephalitis (also known as infectious toxic encephalopathy), a type of reversible brain dysfunction syndrome, may be caused by factors such as systemic toxemia, metabolic disorder, and hypoxia resulting from viral infections [66-68]. Hypoxic injury may lead to further damage to the nervous system. Its clinical symptoms are complex and diverse. The mild course of this disease in patients may show headache, dysphoria, mental disorders, and delirium, while a serious course of infection may develop disorientation, loss of consciousness, coma, and paralysis [66, 69]. COVID-19 patients also suffer from severe hypoxia and viremia [70] and this can cause toxic encephalopathy. Almost $40 \%$ of COVID-19 patients were reported to develop a headache, disturbed consciousness, and other brain dysfunction symptoms [71], and isolated cases of brain tissue edema were also observed during the autopsy. These findings suggest that COVID-19 could also cause infectious toxic encephalopathy in patients. But, more neurological disorders in severe COVID-19 patients may go unnoticed since they are often under sedation. Previous studies indicate that other coronaviruses might invade the peripheral nerve terminals and then gain access to the CNS via a trans-synaptic route [72]. Whether such a trans-synaptic transmission occurs for the SARS-CoV-2 virus is yet to be demonstrated. However, the CT/MRI scanning of a COVID-19 patient was reported to show acute necrotizing encephalopathy, a rare encephalopathy typically associated with a viral infection of the brain tissue [73], indicating a rather direct CNS infection by SARS-CoV-2. Acute necrotizing encephalopathy is frequently associated with intracranial cytokine storm which may lead to the breakdown of the blood-brain barrier (BBB) and increase shedding of viruses [74]. Other proposed possible routes for viral infection of CNS could be hematogenous and lymphatic system. The trans-synaptic route is frequently suspected for the peripheral neuronal manifestations in COVID-19 patients including the loss of smell and taste (Fig. 1). It is also not clear whether the SARS-CoV-2 virus also uses macrophages for a "Trojan horse mechanism" like HIV and penetrate BBB and infect brain cells $[71,75]$.

\section{Evidence of Neurodegeneration from Magnetic Resonance Imaging Studies}

SARS-CoV-2 may also attack the CNS in the early stages of infection. A case report from Italy indicated a sudden neurological impairment with seizures in COVID-19 patients 


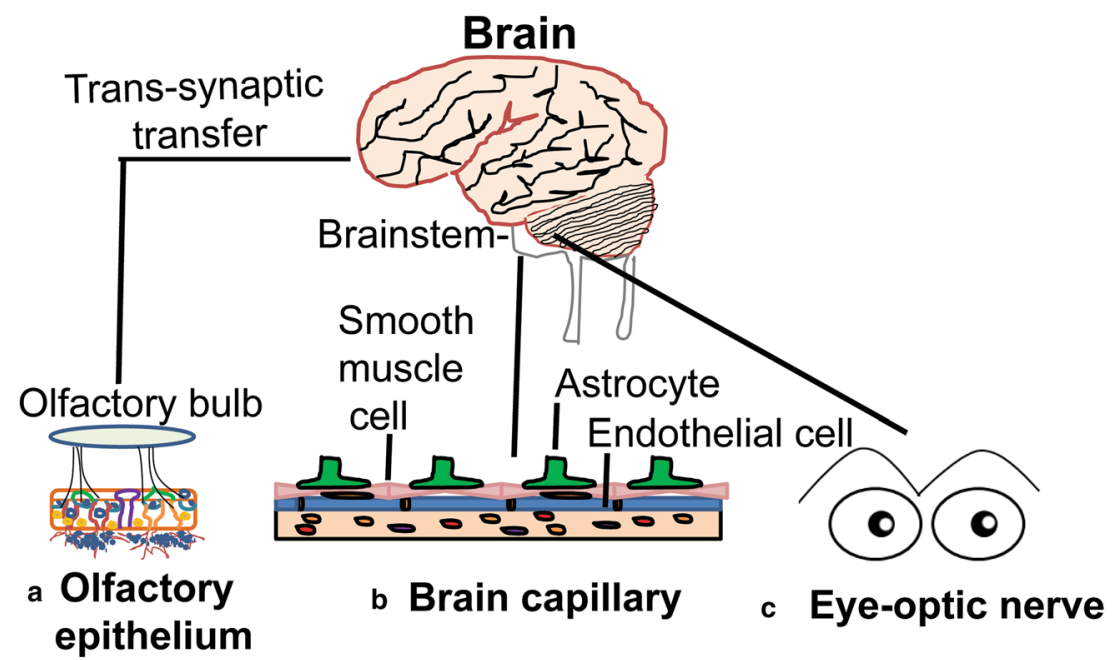

Fig. 1 Potential routes of SARS-CoV-2 entry into the brain. (A) Loss of smell sensation in many of the COVID-19 patients as one of the initial sy65mptoms suggests that the most likely route of viral entry to the brain may be through the olfactory epithelial cells, which abundantly express ACE2, followed by transmission to the olfactory bulb and higher brain regions through trans-synaptic transfer. This mechanism bypasses the BBB. (B) Viral entry through the brain capillary endothelial cells is also

perhaps due to demyelinating lesions in the brain. This speculation is based on the magnetic resonance imaging (MRI) report showing newly diagnosed demyelinating lesions from a COVID-19 patient admitted for interstitial pneumonia and seizures [76]. Hypoxic/ischemic encephalopathy is also reported in $\sim 20 \%$ of 113 deceased patients with COVID-19 [77]. Another study from China reported $36 \%$ of neurological manifestations including cerebrovascular disease and impaired consciousness out of 214 COVID-19 patients [71]. In another study, among 13 patients who underwent MRI, leptomeningeal space enhancement was found in 8 patients, while 11 patients showed bilateral frontotemporal hypoperfusion [78]. Surprisingly, the neurological problems differed significantly during patient admission and during sedation and when neuromuscular blockers were withheld, thus complicating how much is due to SARS-CoV-2 per se or inflammation or drugs [78]. Cortical and olfactory bulb hyperintensity was also seen in some COVID-19 patients by 3-dimensional and 2-dimensional fluid-attenuated inversion methods by MRI [79]. Importantly, there is MRI evidence of early brain stem lesions, also accompanied by lesions and swellings in other regions such as amygdalae, putamen, and thalamic nuclei [65]. The possibility of SARS-CoV-2-induced meningitis was also suggested by the MRI findings of hyperintensity along the wall of the right lateral ventricle and in the right mesial temporal lobe and hippocampus [63]. In children also, alterations in splenium signals were noted in 4 children among 27 infected with SARS-CoV-2, which were accompanied with new-onset neurological symptoms including encephalopathy, headaches, and weakness as well as the brainstem and cerebellar signs, muscle and reduced reflexes likely as they too express very high levels of ACE2. Once endothelial cells are damaged by viral overproduction, the virus can sneak through the underlying smooth muscle cells and finally to astrocytes, microglia, and neurons which also express ACE2. (C) The identification of viral particles in the ocular fluid in some COVID-19 patients also indicates SARS-CoV-2 can infect eyes and through the optic nerve may reach the occipital cortex and other areas of the brain including the brainstem

[80]. Other multiple MRI studies have confirmed hemorrhagic white matter lesions throughout the cerebral hemispheres, deep venous thrombosis with multiple microhemorrhages, chronic infarct, acute or subacute ischemic infarct, and acute hemorrhage, extensive gliosis, and atrophy involving the left temporoparietal lobe [81-84]. In a 6-week-old infant, although MRI scans did not detect any structural lesions, the infant exhibited 2 brief $10-15 \mathrm{~s}$ episodes of upward gaze and bilateral leg stiffening together with EEG abnormalities [85]. Despite high infusion rates of sedative treatments and neuroleptics, about $84 \%$ of COVID-19 patients showed delirium with a combination of acute attention, awareness, and cognition disturbances with MRI abnormalities such as enhancement of subarachnoid spaces, white matter abnormalities, and perfusion abnormalities [86]. Some COVID-19 patients have also shown a loss of peripheral vision [63], loss of olfactory sensation without any MRI abnormality in the olfactory bulb [87], and focal hypodensities on MRI scans in the corpus callosum and the basal ganglia [88].

Previous experimental studies in non-human primates detected $\mathrm{CoV}$ RNA or antigen in the brain and postmortem analysis indicated brain pathology including inflammation and white matter edema when the virus was introduced via the intranasal or intraocular route [89]. Studies are urgently required to test whether the SARS-CoV-2 virus can pass through the intranasal route and cause anosmia which is described as a frequent and early symptom of COVID-19 [90]. In response to viral infections, neurons do not upregulate major histocompatibility complex class I and thus may escape recognition by CD8-positive T cells [91]. However, due to the presence of strong barriers such as blood-nerve (BNB), 
the blood-brain (BBB), and the blood-spinal cord barriers (BSCB), ensures the protection of the nervous system from noxious blood-borne or surrounding stimuli [92].

To gain access to CNS, viruses could first get entry through peripheral neurons using cell machinery of active transport of essential molecules [93]. Preclinical studies in transgenic mice indicated SARS-CoV may enter the brain through the olfactory bulb, leading to rapid transneuronal spread [94]. In the same study, virus antigens were detected abundantly in the olfactory bulb $60-66 \mathrm{~h}$ post-infection. Viral antigen was also detected in regions of the cortex (piriform and infralimbic cortices), basal ganglia (ventral pallidum and lateral preoptic regions), and midbrain (dorsal raphe) indicating the virus spread throughout the CNS [94]. In the case of COVID-19, the neuroinvasive potential of SARS-CoV-2 may also play a major role in the reported respiratory failure in patients. Therefore, more imaging and neuropathology studies are expected to play an important role to detect abnormalities in the olfactory bulb, cranial nerves, and the CNS of COVID-19 patients. Thus, CNS infections by the SARS-CoV-2 virus may promote the development of neurodegenerative disease in people already at risk [95]. A list of neurological manifestations of the SARS-CoV-2 virus in COVID-19 patients is summarized in Table 1.

\section{Viral Infection-Induced Hypoxia and Brain Damage}

The primary infection site for coronavirus is the respiratory tract and cause respiratory depression. Respiratory depression often leads to brain hypoxia which is perhaps the most serious acute health problem [96]. The brain is one of the vital organs which consume a significant amount of energy and oxygen compared to its size due to the high metabolic activity. Reduced oxygen supply to any organ than normal level is referred to as hypoxic condition. In general, reduced levels of oxygen decrease the energy that can be produced by the cell and in turn leads to cell death. Brain hypoxia can lead to brain injury, carbon monoxide poisoning, cardiac arrest or hypotension, respiratory arrest, and stroke. Hypoxic brain results in mild symptoms like temporary loss of memory, problems in coordination of body parts, inattentiveness, and poor judgment. Severe brain hypoxia may lead to coma, seizure, and even brain death [97].

In general, hypoxia due to global ischemia leads to infarction which can damage the pyramidal neurons of the hippocampus, cerebral cortex, and necrosis of the basal ganglia [98]. In experimental models, histologic analysis indicates a shrunken eosinophilic neuron (anoxic neuron) and a red neuron, a representation of dead neuronal cells due to hypoxia [99].

Hypoxia-inducible factor 1-alpha (HIF-1 $\alpha$ ) is considered as the master transcriptional regulator of cellular and developmental response to hypoxia [100-102]. Many viral infections including HIV are reported to influence the HIF- $1 \alpha$ pathway and induce different downstream effects such as altering host cellular metabolism, promoting extracellular vesicle-mediated inflammation, and facilitating viral replication [103]. The mechanism of viral activation of HIF- $1 \alpha$ by hepatitis B, vaccinia, and Epstein-Barr viruses is by stabilizing the HIF- $1 \alpha$ by interfering in the process of HIF- $1 \alpha$ posttranslational prolyl hydroxylation or ubiquitination [104].

COVID-19 patients often suffer from severe hypoxia and viremia which has the potential to cause toxic encephalopathy. In some studies, almost $40 \%$ of COVID-19 patients are reported to suffer from headaches, disturbed consciousness, and other brain dysfunction symptoms [71]. Further, brain edema most likely resulting from hypoxia has been detected in brain tissues of COVID-19 patients by Xu and co-workers [58]. Rapidly developing deteriorating lung function could cause deep hypoxemia and oxygenation provided by prone position has been shown to improve the oxygen supply. The enhanced oxygenation in the prone position could be due to the higher expression of nitric oxide in dorsal lung vessels compared to ventral vessels [105]. These findings imply that hypoxia observed in coronavirus infection may lead to hypoxia-related brain damages.

\section{Stroke and Seizures During COVID-19}

Viral infections also emerged as risk factors for stroke in addition to the well-established risk factors such as hypertension, diabetes, and obesity. Previous studies indicate the Varicella zoster virus, human immunodeficiency virus, and cytomegalovirus is associated with stroke. Virus particles were reported to directly invade into the cerebral arteries corresponding to the areas of infarction to produce vasculopathy [106, 107]. Herpesviruses accelerate atherosclerosis by induction of cytokines (TNF- $\alpha$, IL-2) in response to the specific antigenic stimulus [108]. COVID-19 patients having purple rashes and swollen legs are reported to have blood clots. Another report from Europe suggests that clots arise in $20-30 \%$ of COVID19 patients [109-111]. Even small capillaries of COVID-19 patients were found clogged with clots $[112,113]$. These clots in the smaller capillaries may occlude the blood supply to the brain which can lead to ischemic stroke. A COVID-19 case report with a history of hypertension, diabetes, and end-stage kidney disease on dialysis but with no previous history of seizures developed multiple episodes of seizures and died shortly after the seizure onset [114]. A CT scan also showed chronic microvascular ischemic changes but without any infarct or hemorrhage, suggesting that even microvascular changes are fatal in COVID-19 patients. Several other cases of seizures have been reported in COVID-19 patients with no history of seizures and some patients achieved resolution of seizures with levetiracetam $[82,115]$. Whether such seizures 
Table 1 Nervous systemassociated morbidities in COVID19 patients

\begin{tabular}{llll}
\hline No & Morbidity & Affected region & Reference \\
\hline 1 & Encephalitis & CSF & 63,64 \\
2 & Brain edema & Brainstem & 65 \\
3 & Ischemic stroke & Cortex & 71 \\
4 & Brain hemorrhage & Temporal lobe & 73 \\
5 & Demyelinating lesion & Spinal cord & 76 \\
6 & Impaired consciousness & Whole brain & 71 \\
7 & Anosmia & Olfactory neurons & 93 \\
8 & Seizures & Left temporoparietal lobe & $99-101$ \\
9 & Guillain-Barré Syndrome & Peripheral nerve demyelination & $102-109$ \\
10 & Anosmia & Olfactory epithelium & $115-118$ \\
11 & Ageusia & Tongue nerves & $115-118$ \\
12 & Headache & Whole brain & $66,69,71$ \\
13 & Myalgia-muscle pain & Neuromuscular junction & 110,111 \\
14 & delirium & Whole brain & 112 \\
15 & Rhabdomyolysis & Muscle & 113 \\
16 & Dizziness & Whole brain & 114 \\
17 & Confusion & Whole brain & 11 \\
\hline
\end{tabular}

are secondary to multi-system organ failure or brain intravascular coagulopathy-related brain injury is not yet clear.

\section{Peripheral Nervous System-Associated Comorbidities}

\section{Guillain-Barré Syndrome and Coronavirus}

Guillain-Barre syndrome (GBS) is a condition in which the immune system mistakenly attacks the peripheral nervous system and it is the most common cause of acute flaccid paralysis. The initial symptoms are weakness and tingling in the periphery, but can quickly spread and paralyze the whole body. About two-thirds of the cases are associated with viral infections like H1N1, zika, and influenza [116]. The first case of GBS was reported from China in a 61-year-old woman infected with the coronavirus [117]. A neurological examination indicated symmetric weakness and areflexia in both legs and feet. These symptoms were reported to progress within 3 days after admission and the sensation to light touch and pinprick was reported to decrease distally [117]. Another case of GBS was recently reported from Italy in a 71-year-old male COVID-19 patient without any previous neurological history with normal brain CT scan findings [118]. The absence of both the sural nerve sensory nerve action potential (SAP) and the tibial nerve compound muscle action potential (CMAP) by electroneurography measurements indicated peripheral neuropathy resulting from demyelination, typical of GBS. To date, 73 other cases of GBS have been confirmed in COVID-19 patients with male predominance around the world [119-123]. Fortunately, following immunoglobulin treatment, GBS symptoms were resolved in more than $70 \%$ of COVID-19 patients [123]. However, whether the SARS$\mathrm{CoV}-2$ virus itself can cause GBS or secondary to other infections in COVID-19 patients such as dengue [124] remains to be determined.

\section{Loss of Smell and Taste in COVID-19}

Several case studies have indicated that the SARS-CoV-2 virus can cause both smell and/or taste disorders (STDs). Loss of smell function can arise from various causes like head trauma, toxic substance exposure, diseases like Alzheimer's, Parkinson's, and notably acute viral upper respiratory infections that damage the olfactory neuroepithelium, called a postviral olfactory disorder. Many viruses have the tendency to invade the brain via olfactory fila [125-127]. Viral infections may lead to transient olfactory dysfunction through an inflammatory reaction of the nasal mucosa and the development of rhinorrhea. It also occurs in some coronavirus infections [128, 129]. COVID-19 related olfactory dysfunction may not be associated with rhinorrhea [130]. The most common complaints in COVID-19 patients with peripheral nervous system-related symptoms are hypogeusia (5.6\%) and hyposmia (5.1\%) [71]. One study of the COVID-19 patients indicated that the prevalence of olfactory and gustatory dysfunction is significantly higher in the European population. It is also reported that in COVID-19 cases, the olfactory disorder may appear before the rest of the complaints in $11.8 \%$ of cases suggesting that the olfactory symptom is important for early detection of the disease [130]. The pathophysiological 
mechanisms for the olfactory and gustatory dysfunctions in the COVID-19 patients are still not clear but anosmia is common to infections by coronavirus family [128]. Sudden partial or complete loss of the sense of smell (Anosmia) and loss of taste (Ageusia) is reported to occur at the early stage of COVID-19 infections [130, 131]. Previous studies suggested that some specific viruses including SARS-CoV-2 could cause postviral olfactory dysfunction through mechanisms other than nasal obstruction indicating that coronaviruses can directly affect the olfactory sensory epithelium [131]. Another clinical study conducted with 33 COVID-19 patients reported chemosensitive dysfunction in 21 patients $(63.6 \%)$ and 13 patients out of 33 reported combined gustatory and olfactory disorders [132]. These studies imply that the SARS-CoV-2 virus can cause both anosmia and hyposmia, but many patients recover from these disorders suggesting reversibility due to repair of the damaged structures.

\section{Somatic Symptom Disorder}

Despite being common in COVID-19 patients, somatic symptom disorder (SSD) was ignored for a long period. SSD is associated with the interaction of biology, cognition, emotion, behavior, and environment. The five major symptoms include chest discomfort and palpitation, dyspnea, nausea, headache, and dizziness. A case of a 16-year-old adolescent with extreme and persisting health preoccupations responded rapidly to a low dose of antipsychotic and an antidepressant [133]. In China, ICU nurses were found to be particularly vulnerable to SSD with varying and overlapping SSD symptoms which were mostly associated with PPE failure [134]. Similarly, Italian health care workers exhibited increased irritability, a change in food habits, difficulty falling asleep, and muscle tension [135]. Similar cases have been reported from Brazil [136] and India [137]. Thus, strong support is emerging on the negative impact of the COVID-19 pandemic on the mental health issues such as anxiety, depression, anger, somatic symptoms, and sleep problems, particularly in health care workers.

\section{Silent Hypoxemia}

Silent hypoxemia (SH), also called happy hypoxemia observed in many COVID-19 patients, is baffling many physicians. Silent hypoxemia or apathetic hypoxemia refers to COVID-19 patients without dyspnea exhibiting very low oxygen levels incompatible with life [138]. A case report of three COVID-19 patients exhibited no difficulty with breathing even with low oxygen tension [139]. These patients show so low blood-oxygen levels that they should be either unconscious or multiple organs should have failed, yet they are awake and not struggling to breathe, defying all our understanding of basic biology [140]. It should be noted that silent hypoxemia is dangerous because such patients may show minimal symptoms yet rapidly develop multi-organ failure leading to death due to low peripheral oxygen levels [138]. The respiratory neural centers are exquisitely sensitive to $\mathrm{PCO}_{2}$, even a small increase rapidly evoke large increases in minute ventilation of respiratory discomfort [141]. Several mechanisms are proposed to account for $\mathrm{SH}$, including direct action of SARS-CoV-2 on the receptors involved in chemosensitivity to oxygen, altered responses by the dyspnea and the respiratory centers to low levels of oxygen, and the way $\mathrm{PCO}_{2}$ blunts the brain's response to hypoxia [139]. Another hypothesis suggests that SARS-CoV-2-mediated neuronal damage in the corticolimbic network may lead to the altered secretion of endogenous neuropeptides or neurotransmitters that are involved in perceptual effects [142]. Future studies are required to confirm or disprove these hypotheses.

\section{Long-Term Neurological Effects}

Surprisingly, some COVID-19 patients who recovered from non-neurological manifestations of the disease within weeks start showing many neurological symptoms including brain fog even after several months. Although systematic studies of these so-called long-haulers are still lacking, anecdotal case reports have listed hallucinations, double vision, numbness in their limbs or face, disorientation, and difficulty in concentrating even after 5 to 6 months following SARS-CoV-2 infection. Several patients have complained their most debilitating and persistent symptom is the inability to remember words or even keep track of medication. Loss of smell and taste can also linger for many long-haulers. A hospital in Paris reported having seen as many as 30 long-haulers every week between mid-May and late July 2020. In one study, 55\% of 60 patients showed neurological symptoms even after 3 months [143], suggesting possible disruptions to microstructural and functional brain integrity underscoring the long-term consequences of SARS-CoV-2. Since COVID-19 is a new disease, the exact reason why some of these patients have not yet recovered is still unknown, but myalgic encephalomyelitis/ chronic fatigue syndrome (ME/CFS) has been suggested to be the cause of the lingering brain fog. Although the number of long-haulers reported so far is still small, considering the scale of the COVID-19 pandemic, thousands of patients may already be suffering from brain-related symptoms worldwide, and if the virus has indeed caused irreversible damage to neurons, they may have to suffer life-long.

\section{Mechanism of Neuronal Dysfunction}

The number of COVID-19 patients that show neurological impairment may not reflect the true numbers, as many patients are sedated and are on ventilators. Among the 
severe cases of COVID-19, neurological manifestations including the loss of consciousness were found in about $88 \%$ of patients in some studies [63]. Loss of taste and smell being the initial symptom in many patients, a very likely route of initial viral invasion is through the nose, then moving upward through the olfactory bulb, and then finally to higher brain regions including the brainstem, all by trans-synaptic transfer, a process that bypasses the BBB (Fig. 1). The trans-synaptic transfer of SARS-CoV2 from the periphery to the cortex and the brainstem is a very likely mechanism because of several reasons. First, several other viruses including HEV67 [144, 145], avian bronchitis virus [146, 147], alpha herpesvirus [148], West Nile virus [149], SARS-CoV [94], and MERS-CoV [150] are known to utilize this mechanism, at least in experimental models. Second, viral particles such as HSV1 [151, 152], rabies virus [153, 154], SARS-CoV [94, 155], and MERS-CoV [150] are heavily detected in the brainstem. Third, there are established neuroanatomic connections between brainstem nuclei such as solitary tract and the mechanoreceptors and chemoreceptors in the lung and respiratory tracts $[154,156]$ as well as between nucleus ambiguous of the brainstem and the airway cells [157]. Finally, some mutations may predispose the brainstem to be vulnerable to viral invasion as has been demonstrated for HSV1 [158]. Thus, spontaneous loss of breathing reported in COVID-19 patients [72, 159] may be due to the dysfunction of the cardiorespiratory center in the brainstem. Indeed, in a case report, three patients recovered from pneumonia but failed to wean from invasive mechanical ventilation due to brainstem dysfunction and central respiratory drive depression [160]. Recent findings that the SARS-CoV-2 virus is neurotoxic [161, $162]$ in particular to the brainstem neurons $[72,160]$ are consistent with the idea that SARS-CoV-2 mediates respiratory failure through degeneration of brainstem neurons, most likely by rupture of neurons due to viral budding [163]. Repeat CT scans also confirm that the damage occurs first in the brainstem then spreads to other brain regions [65]. Normally, breathing is an involuntary (autonomous) process regulated by pacemaker cells in the pre-Bötzinger complex (pre-BÖTC) area of the brainstem in response to changes in $\mathrm{PCO}_{2}, \mathrm{PO}_{2}$, or $\mathrm{H}^{+}$ ion concentration of the arterial blood $[164,165]$. But, both inspiration and expiration are also regulated voluntarily through direct input from motor neurons in the cortex to the respiratory muscle [165], thereby bypassing the brainstem. Thus, we now have clear pieces of evidence that spontaneous loss of breathing seen in COVID-19 patients is due to damage to the central respiratory regulatory neurons in the brainstem While this evidence is helpful, elucidation of the actual molecular mechanism of SARS-CoV-2-induced neuronal dysfunction that leads to respiratory failure is crucial to immediately undertake prevention strategies as well as for the initiation of mechanism-based treatments. Also, more mechanistic insights on pathophysiology by which the SARS-CoV-2 virus affects olfactory and gustatory functions need to be identified so that prompt treatments can be initiated.

SARS-CoV-2 gains entry into cells by the efficient binding of the spike viral protein $\mathrm{S} 1$ to the ACE2 protein facilitated by the protease TMPSS 2 by clathrin-dependent endocytosis of the complex [166]. One major role of the ACE2 enzyme is the conversion of angiotensin II to angiotensin I thereby reduce the deleterious effects of angiotensin II such as decreased nitric oxide (NO) generation, oxidation, vasoconstriction, inflammation, and thrombosis by binding to AT1 receptors $\left(\mathrm{AT}_{1} \mathrm{R}\right)$ [167]. ACE2 also converts angiotensin II to angiotensin 1-7 which exerts salutary and opposite effects of angiotensin II including vasodilation and reduced inflammation through Mas receptor signaling (MasR) [168] (Fig. 2).

Further, there is now evidence that spike protein interaction with the ACE2 downregulates ACE2 expression [169]. This in turn invariably increases ACE1 signaling including increased conversion of angiotensin I to angiotensin II as a compensatory mechanism thereby decrease NO production and increase oxidative stress, inflammation, and neurodegeneration in the CNS. Cytokine storm representing increased proinflammatory interleukins in COVI-19 patients is now well established [77, 170]. Several postmortem reports suggest that COVID-19 patients show severe endothelial damage and COVID-19 is turning to be a disease of endothelial dysfunction [44]. Such endothelial damage can also occur in the brain capillaries leading to disruption of BBB and budding of the viral particles from the capillary endothelium to the brain. Finding of SARS-CoV-2 virions in the CSF of COVID-19 patients [63] supports this interpretation. Endothelial damage in cerebral capillaries can also result in bleeding with fatal consequences in COVID-19 patients. Indeed, exposure of 3D brain organoids to convalescent plasma from COVID-19 patients showed SARS-CoV-2 virions in neurons within 2 days. Importantly, the infected neurons displayed missorted tau protein, hyperphosphorylation of tau, and neuronal death [171]. The neurodegeneration or neuronal dysfunction may be responsible for a wide range of neurological issues reported in COVID-19 patients (Fig. 2).

\section{Conclusion}

Similar to other coronaviruses, the SARS-CoV-2 virus has been found in the brain parenchyma and CSF of COVID-19 patients, implying the neurotrophic property of this virus and 


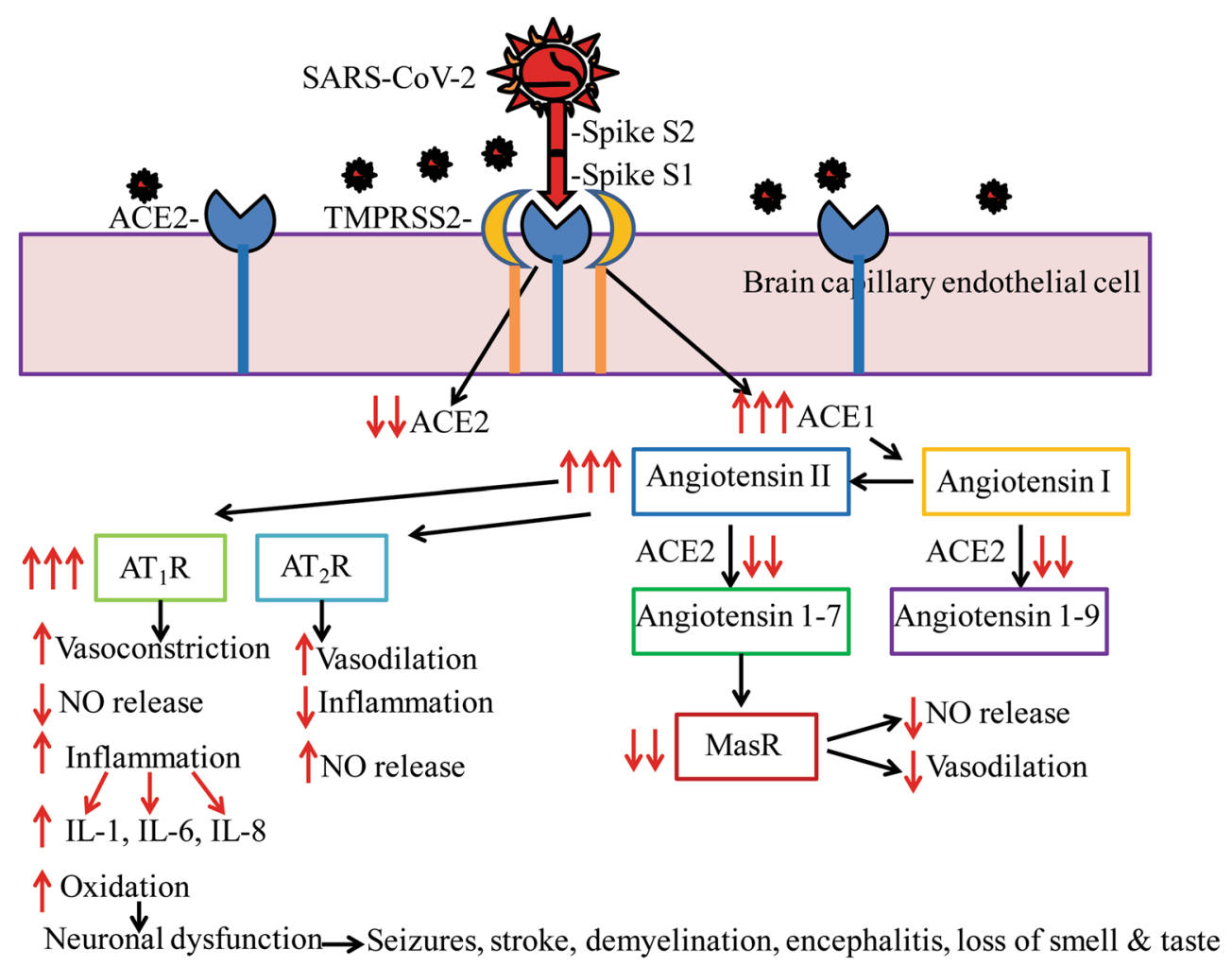

Fig. 2 SARS-CoV-2-mediated neurodegeneration may be due to the downregulation of ACE2-mediated signaling and concomitant increase in ACE1-mediated neuroinflammation. SARS-CoV-2 binds ACE2 through the receptor-binding domain (RBD) of spike protein $\mathrm{S} 1$ facilitated by protease TMPRSS2, resulting in reduced functional ACE2 expression which in turn enhances ACE1 signaling including increased conversion of angiotensin I to angiotensin II. ACE2 is responsible for the conversion of angiotensin I into angiotensin 1-9 which increases nitric oxide (NO) generation and vasodilation. With reduced ACE2, angiotensin 1-9 levels are reduced and therefore NO generation is also reduced. ACE2 is also responsible for the conversion of angiotensin II into angiotensin 1-7 which enhances Mas receptor (MasR) signaling to increase vasodilation and to prevent fibrosis. With the reduction in ACE2, MasR signaling is also reduced. Increased angiotensin II levels due to decreased ACE2 activity can also enhance signaling through the type-1a $\left(\mathrm{AT}_{1} \mathrm{R}\right)$ or type$2\left(\mathrm{AT}_{2} \mathrm{R}\right)$ angiotensin receptors. Activation of $\mathrm{AT}_{2} \mathrm{R}$ is normally neuroprotective. However, increased $\mathrm{AT}_{1} \mathrm{R}$ signaling leads to reduced $\mathrm{NO}$ generation, and therefore vasoconstriction, $\mathrm{AT}_{1} \mathrm{R}$ signaling also increases oxidative stress and neuroinflammation with the overproduction of interleukins such as IL-1, IL-6, IL-8, and IL-29, all of which were confirmed in COVID-19 patients. Increased neuroinflammation in turn can cause neurodegeneration, brain dysfunction, and a variety of neurological issues as seen among COVID-19 patients. A schematic representation of a signal transduction mechanism is shown for endothelial cells of brain capillaries, and a similar mechanism is also expected in neurons and glia which also has been shown to express ACE2 its potential to cause neurological disorders. Distribution of ACE2 receptor in the peripheral and central nervous system neurons and other cells, though at low expression levels, is consistent with the neurological manifestation of SARS-CoV2. Indeed, similar to intracranial infections by other viruses, COVID-19 patients show a wide range of CNS symptoms including headache, confusion, dizziness, seizures, disturbed consciousness, stroke, intracranial hemorrhage, peripheral nerve demyelination, and sudden loss of smell and taste [172-178]. In particular, loss of smell and taste should be recognized as an important and early nervous systemrelated symptom in COVID-19 patients. While some of these symptoms may be due to direct neural invasion of the virus, others may result from metabolic and systemic complications. Nevertheless, the most important of all symptoms appears to be loss of ability to breathe on their own requiring ventilators in some patients. It will be interesting to investigate whether the dysfunction of cardiopulmonary regulatory centers in the thalamus and brainstem is responsible for the loss of spontaneous breathing. SARS-CoV-2 being a novel virus, more clinical and basic science studies are required so that appropriate therapy can be timely initiated based on the identified mechanism.

Acknowledgments We thank all the administrative and technical staff in the Department of Immunology and Nano-Medicine, Herbert Wertheim College of Medicine (HWCOM), Florida International University.

Author's Contributions Lakshmana MK, Chand HS, and Nair M designed the strategy; Lakshmana MK, Mohan Kumar MK, and Devadoss D collected literature and analyzed the data; Lakshmana MK, Mohan Kumar MK, and Devadoss wrote the manuscript, and Chand HS and Nair M contributed to Figs. 1 and 2. All authors reviewed the manuscript. 
Funding This work was supported by a grant from the National Institute of Health (No. 1R01DA052271) to MN and (No. 3R21AI144374-02S1) to HSC.

Data Availability All data are contained within the manuscript.

\section{Compliance with Ethical Standards}

Conflict of Interest The authors declare that they have no competing interests.

Consent to Participate Not applicable.

Consent for Publication Not applicable.

\section{References}

1. Wu C, Liu Y, Yang Y, Zhang P, Zhong W, Wang Y, Wang Q, Xu $Y$ et al (2020) Analysis of therapeutic targets for SARS-CoV-2 and discovery of potential drugs by computational methods. Acta Pharm Sin B 10(5):766-788. https://doi.org/10.1016/j.apsb.2020. 02.008

2. Baig AM, Khaleeq A, Ali U, Syeda H (2020) Evidence of the COVID-19 virus targeting the CNS: tissue distribution, hostvirus interaction, and proposed neurotropic mechanisms. ACS Chem Neurosci 11(7):995-998. https://doi.org/10.1021/ acschemneuro.0c00122

3. Chen Y, Liu Q, Guo D (2020) Emerging coronaviruses: genome structure, replication, and pathogenesis. J Med Virol 92:418-423. https://doi.org/10.1002/jmv.25681

4. Chen Y, Guo Y, Pan Y, Zhao ZJ (2020) Structure analysis of the receptor binding of 2019-nCoV. Biochem Biophys Res Commun 525(1):135-140. https://doi.org/10.1016/j.bbrc.2020.02.071

5. Walls AC, Park YJ, Tortorici MA, Wall A, McGuire AT, Veesler D (2020) Structure, function, and antigenicity of the SARS-CoV-2 spike glycoprotein. Cell 181:281-292 e6. https://doi.org/10.1016/ j.cell.2020.02.058

6. Letko M, Marzi A, Munster V (2020) Functional assessment of cell entry and receptor usage for SARS-CoV-2 and other lineage B betacoronaviruses. Nat Microbiol 5:562-569. https://doi.org/10. 1038/s41564-020-0688-y

7. Xia H, Lazartigues E (2008) Angiotensin-converting enzyme 2 in the brain: properties and future directions. J Neurochem 107: 1482-1494. https://doi.org/10.1111/j.1471-4159.2008.05723.x

8. Abiodun OA, Ola MS (2020) Role of brain renin angiotensin system in neurodegeneration: an update. Saudi J Biol Sci 27: 905-912. https://doi.org/10.1016/j.sjbs.2020.01.026

9. Li MY, Li L, Zhang XS (2020) Expression of the SARS-CoV-2 cell receptor gene ACE2 in a wide variety of human tissues. Infect Dis Poverty 9:45. https://doi.org/10.1186/s40249-020-00662-x

10. Huang C, Wang Y, Li X, Ren L, Zhao J, Hu Y, Zhang L, Fan G, $\mathrm{Xu}$ J, Gu X, et. al (2020) Clinical features of patients infected with 2019 novel coronavirus in Wuhan, China. Lancet 395 (10233): 497-506. https://doi.org/10.1016/S0140-6736(20)30183-5

11. Chen N, Zhou M, Dong X, Qu J, Gong F, Han Y, Qiu Y, Wang J et al (2020) Epidemiological and clinical characteristics of 99 cases of 2019 novel coronavirus pneumonia in Wuhan, China: a descriptive study. Lancet. 395(10223):507-513. https://doi.org/ 10.1016/S0140-6736(20)30211-7

12. Holshue ML, DeBolt C, Lindquist S, Lofy KH, Wiesman J, Bruce H, Spitters C, Ericson K et al (2020) First case of 2019 novel coronavirus in the United States. N Engl J Med 382(10):929936. https://doi.org/10.1056/NEJMoa2001191

13. Donoghue $\mathrm{M}$, Hsieh F, Baronas E, Godbout $\mathrm{K}$, Gosselin $\mathrm{M}$, Stagliano N, Donovan M, Woolf B et al (2020) A novel angiotensin-converting enzyme-related carboxypeptidase (ACE2) converts angiotensin I to angiotensin 1-9. Circ Res 87(5):E1-E9. https://doi.org/10.1161/01.res.87.5.e1

14. Tipnis SR, Hooper NM, Hyde R, Karran E, Christie G, Turner AJ (2000) A human homolog of angiotensin-converting enzyme. Cloning and functional expression as a captopril-insensitive carboxypeptidase. J Biol Chem 275:33238-33243. https://oi.org/ 10.1074/jbc.M002615200

15. Cantuti-Castelvetri L, Ojha R, Pedro LD, Djannatian M, Franz J, Kuivanen S, van der Meer F, Kallio K et al (2020) Neuropilin-1 facilitates SARS-CoV-2 cell entry and infectivity. Science. 370(6518):856-860

16. Daly JL, Simonetti B, Antón-Plágaro C, Kavanagh Williamson M, Shoemark DK, Simón-Gracia L, Klein K, Bauer M, Hollandi $\mathrm{R}$, Greber UF, et al Neuropilin-1 is a host factor for SARS-CoV-2 infection

17. Bittmann S, Weissenstein A, Moschüring-Alieva E, Villalon G, Villalon G (2020) Neuropilin-1 in transmission process of COVID-19. J Regen Biol Med 2:1-2

18. Roy S, Bag AK, Singh RK, Talmadge JE, Batra SK, Datta K (2017) Multifaceted role of neuropilins in the immune system: potential targets for immunotherapy. Front Immunol 8:1228. https://doi.org/10.3389/fimmu.2017.01228

19. Bagri A, Tessier-Lavigne M (2002) Neuropilins as Semaphorin receptors: in vivo functions in neuronal cell migration and axon guidance. Adv Exp Med Biol 515:13-31

20. Davies J, Randeva HS, Chatha K, Hall M, Spandidos DA, Karteris E, Kyrou I (2020) Neuropilin-1 as a new potential SARS-CoV-2 infection mediator implicated in the neurologic features and central nervous system involvement of COVID-19. Mol Med Rep 22(5):4221-4226

21. Moutal A, Martin LF, Boinon L, Gomez K, Ran D, Zhou Y, Stratton HJ, Cai S et al (2020) SARS-CoV-2 Spike protein coopts VEGF-A/Neuropilin-1 receptor signaling to induce analgesia. bioRxiv [Preprint] 2020.07.17.209288

22. Perez-Miller S, Patek M, Moutal A, Cabel CR, Thorne CA, Campos SK, Khanna R (2020) In silico identification and validation of inhibitors of the interaction between neuropilin receptor 1 and SARS-CoV-2 Spike protein. bioRxiv [Preprint] 2020.09.22.308783

23. Liu W, Zhang Q, Chen J, Xiang R, Song H, Shu S, Chen L, Liang L et al (2020) Detection of COVID-19 in children in early January 2020 in Wuhan, China. N Engl J Med 382:1370-1371. https://doi. org/10.1056/NEJMc2003717

24. Wu Y, Guo W, Liu H, Qi B, Liang K, Xu H, Peng Z, Xiao SY (2020) Clinical outcomes of 402 patients with COVID-2019 from a single center in Wuhan, China. J Med Virol 92:2151-2157. https://doi.org/10.1002/jmv.26168

25. Tian S, Liu H, Liao M, Wu Y, Yang C, Cai Y, Peng Z, Xiao SY (2020) Analysis of mortality in patients with COVID-19: clinical and laboratory parameters. Open forum Infect Dis 7(5):ofaa152. https://doi.org/10.1093/ofid/ofaa152

26. Applegate WB, Ouslander JG (2020) COVID-19 presents high risk to older persons. J Am Geriatr Soc 68:681. https://doi.org/ 10.1111 /jgs. 16426

27. Koff WC, Williams MA (2020) COVID-19 and immunity in aging populations - a new research agenda. N Engl J Med 383(9): 804-805. https://doi.org/10.1056/NEJMp2006761

28. Le Couteur DG, Anderson RM, Newman AB (2020) COVID-19 through the lens of gerontology. J Gerontol A Biol Sci Med Sci 75(9):e119-e120. https://doi.org/10.1093/gerona/glaa077 
29. Promislow DEL (2020) A geroscience perspective on COVID-19 mortality. J Gerontol A Biol Sci Med Sci 75(9):e30-e33. https:// doi.org/10.1093/gerona/glaa094

30. Wu C, Chen X, Cai Y, Xia J, Zhou X, Xu S, Huang H, Zhang L et al (2020) Risk factors associated with acute respiratory distress syndrome and death in patients with coronavirus disease 2019 pneumonia in Wuhan, China. JAMA Intern Med 180(7):934943. https://doi.org/10.1001/jamainternmed.2020.0994

31. Zimmermann P, Curtis N (2020) Coronavirus infections in children including COVID-19: an overview of the epidemiology, clinical features, diagnosis, treatment and prevention options in children. Pediatr Infect Dis J 39:355-368. https://doi.org/10.1097/ INF.0000000000002660

32. Alzamora MC, Paredes T, Caceres D, Webb CM, Valdez LM, La Rosa M (2020) Severe COVID-19 during pregnancy and possible vertical transmission. Am J Perinatol 37(8):861-865. https://doi. org/10.1055/s-0040-1710050

33. Vivanti AJ, Vauloup-Fellous C, Prevot S, Zupan V, Suffee C, Cao JD, Benachi A, Luca BD (2020) Transplacental transmission of SARS-CoV-2 infection. Nat Commun 11(1):3572. https://doi.org/ 10.1038/s41467-020-17436-6

34. Vankadari N, Wilce JA (2020) Emerging WuHan (COVID-19) coronavirus: glycan shield and structure prediction of spike glycoprotein and its interaction with human CD26. Emerg Microbes Infect 9:601-604. https://doi.org/10.1080/22221751.2020. 1739565

35. Sargiacomo C, Sotgia F, Lisanti MP (2020) COVID-19 and chronological aging: senolytics and other anti-aging drugs for the treatment or prevention of coronavirus infection? Aging (Albany NY) 12:6511-6517. https://doi.org/10.18632/aging.103001

36. Li JW, Han TW, Woodward M, Anderson CS, Zhou H, Chen YD, Neal B (2020) The impact of 2019 novel coronavirus on heart injury: a systematic review and meta-analysis. Prog Cardiovasc Dis S0033-0620(20):30080-30083. https://doi.org/10.1016/j. pcad.2020.04.008

37. Atri D, Siddiqi HK, Lang J, Nauffal V, Morrow DA, Bohula EA (2020) COVID-19 for the cardiologist: a current review of the virology, clinical epidemiology, cardiac and other clinical manifestations and potential therapeutic strategies. JACC Basic Transl Sci 5(5):518-536. https://doi.org/10.1016/j.jacbts.2020.04.002

38. Inciardi RM, Lupi L, Zaccone $\mathrm{G}$ et al (2020) Cardiac involvement in a patient with coronavirus disease 2019 (COVID-19). JAMA Cardiol 5(7):819-824. https://doi.org/10.1001/jamacardio.2020. 1096

39. Guo T, Fan Y, Chen M et al (2020) Cardiovascular implications of fatal outcomes of patients with Coronavirus Disease 2019 (COVID-19). JAMA Cardiol 5(7):811-818. https://doi.org/10. 1001/jamacardio.2020.1017

40. Bulfamante GP, Perrucci GL, Falleni L, Sommariva E, Tosi D, Martinelli C, Songia P, Poggio P et al (2020) Evidence of SARSCoV-2 transcriptional activity in cardiomyocytes of COVID-19 patients without clinical signs of cardiac involvement. MedRxiv 2020(08):24.20170175. https://doi.org/10.1101/2020.08.24. 20170175

41. Dolhnikoff M, Ferreira Ferranti J, de Almeida Monteiro RA, Duarte-Neto AN, Soares Gomes-Gouvêa M, Viu Degaspare N, Figueiredo Delgado A, Montanari Fiorita C et al (2020) SARSCoV-2 in cardiac tissue of a child with COVID-19-related multisystem inflammatory syndrome. Lancet Child Adolesc Health 4(10):790-794. https://doi.org/10.1016/S2352-4642(20)30257-1

42. Ferrario CM, Jessup J, Chappell MC et al (2005) Effect of angiotensin-converting enzyme inhibition and angiotensin II receptor blockers on cardiac angiotensin-converting enzyme 2 . Circulation. 111(20):2605-2610. https://doi.org/10.1161/ CIRCULATIONAHA.104.510461
43. Monteil V, Kwon H, Prado P et al (2020) Inhibition of SARS$\mathrm{CoV}-2$ infections in engineered human tissues using clinical-grade soluble human ACE2. Cell 181(4):905-913.e7. https://doi.org/10. 1016/j.cell.2020.04.004

44. Varga Z, Flammer AJ, Steiger P et al (2020) Endothelial cell infection and endotheliitis in COVID-19. Lancet 395(10234): 1417-1418. https://doi.org/10.1016/S0140-6736(20)30937-5

45. Ackermann M, Verleden SE, Kuehnel M et al (2020) Pulmonary vascular endothelialitis, thrombosis, and angiogenesis in COVID19. N Engl J Med 383(2):120-128. https://doi.org/10.1056/ NEJMoa2015432

46. Mosleh W, Chen K, Pfau SE, Vashist A (2020) Endotheliitis and endothelial dysfunction in patients with COVID-19: its role in thrombosis and adverse outcomes. J Clin Med 9(6):1862. https:// doi.org/10.3390/jcm9061862

47. Huertas A, Montani D, Savale L, Pichon J, Tu L, Parent F, Guignabert C, Humbert M (2020) Endothelial cell dysfunction: a major player in SARS-CoV-2 infection (COVID-19)? Eur Respir J 56(1):2001634. https://doi.org/10.1183/13993003. 01634-2020

48. Cure E, Cumhur CM (2020) Angiotensin-converting enzyme inhibitors and angiotensin receptor blockers may be harmful in patients with diabetes during COVID-19 pandemic. Diabetes Metab Syndr 14:349-350. https://doi.org/10.1016/j.dsx.2020.04.019

49. Roncon L, Zuin M, Rigatelli G, Zuliani G (2020) Diabetic patients with COVID-19 infection are at higher risk of ICU admission and poor short-term outcome. J Clin Virol 127:104354. https://doi.org/ 10.1016/j.jcv.2020.104354

50. Zhou F, Yu T, Du R, Fan G, Liu Y, Liu Z, Xiang J, Wang Y et al (2020) Clinical course and risk factors for mortality of adult inpatients with COVID-19 in Wuhan, China: a retrospective cohort study. Lancet 395:1054-1062. https://doi.org/10.1016/S01406736(20)30566-3

51. Watanabe M, Risi R, Tuccinardi D, Baquero CJ, Manfrini S, Gnessi L (2020) Obesity and SARS-CoV-2: a population to safeguard. Diabetes Metab Res Rev:e3325. https://doi.org/10.1002/ dmrr. 3325

52. Zheng KI, Gao F, Wang XB, Sun QF, Pan KH, Wang TY, Ma HL, Liu WY et al (2020) Obesity as a risk factor for greater severity of COVID-19 in patients with metabolic associated fatty liver disease. Metabolism 108:154244. https://doi.org/10.1016/j. metabol.2020.154244:154244

53. Liu C, Jiang ZC, Shao CX, Zhang HG, Yue HM, Chen ZH, Ma BY, Liu WY et al (2020) Preliminary study of the relationship between novel coronavirus pneumonia and liver function damage: a multicenter study. Zhonghua Gan Zang Bing Za Zhi 28:107111. https://doi.org/10.3760/cma.j.issn.1007-3418.2020.02.003

54. Li Y, Xiao SY (2020) Hepatic involvement in COVID-19 patients: pathology, pathogenesis, and clinical implications. J Med Virol. https://doi.org/10.1002/jmv.25973

55. Qi X, Liu C, Jiang Z, Gu Y, Zhang G, Shao C, Yue H, Chen Z et al (2020) Multicenter analysis of clinical characteristics and outcome of COVID-19 patients with liver injury. J Hepatol 73(2):455-458. https://doi.org/10.1016/j.jhep.2020.04.010

56. Cheng Y, Luo R, Wang K, Zhang M, Wang Z, Dong L, Li J, Yao $\mathrm{Y}$ et al (2020) Kidney disease is associated with in-hospital death of patients with COVID-19. Kidney Int 97:829-838. https://doi. org/10.1016/j.kint.2020.03.005

57. Zhang C, Shi L, Wang FS (2020) Liver injury in COVID-19: management and challenges. Lancet Gastroenterol Hepatol 5(5): 428-430. https://doi.org/10.1016/S2468-1253(20)30057-1

58. Xu Z, Shi L, Wang Y et al (2020) Pathological findings of COVID-19 associated with acute respiratory distress syndrome [published correction appears in Lancet Respir Med. 2020 Feb 25]. Lancet Respir Med 8(4):420-422. https://doi.org/10. 1016/S2213-2600(20)30076-X 
59. Rismanbaf A, Zarei S (2020) Liver and kidney injuries in COVID19 and their effects on drug therapy: a letter to editor. Arch Acad Emerg Med 8(1):e17. https://doi.org/10.22037/aaem.v8i1.590

60. Michalicová A, Bhide K, Bhide M, Kováč A (2017) How viruses infiltrate the central nervous system. Acta Virol 61(4):393-400. https://doi.org/10.4149/av_2017_401

61. Wright EJ, Brew BJ, Wesselingh SL (2008) Pathogenesis and diagnosis of viral infections of the nervous system. Neurol Clin 26(3):617-vii. https://doi.org/10.1016/j.ncl.2008.03.006

62. Ellul M, Solomon T (2018) Acute encephalitis - diagnosis and management. Clin Med (Lond) 18(2):155-159. https://doi.org/ 10.7861/clinmedicine.18-2-155

63. Moriguchi T, Harii N, Goto J et al (2020) A first case of meningitis/encephalitis associated with SARS-Coronavirus-2. Int J Infect Dis 94:55-58. https://doi.org/10.1016/j.ijid.2020.03. 062

64. Wu Y, Xu X, Chen Z et al (2020) Nervous system involvement after infection with COVID-19 and other coronaviruses [published online ahead of print, 2020 mar 30]. Brain Behav Immun S08891591(20):30357-30353. https://doi.org/10.1016/j.bbi.2020.03. 031

65. Dixon L, Varley J, Gontsarova A et al (2020) COVID-19-related acute necrotizing encephalopathy with brain stem involvement in a patient with aplastic anemia. Neurol Neuroimmunol Neuroinflamm 7(5):e789. https://doi.org/10.1212/NXI. 0000000000000789

66. Mizuguchi M, Yamanouchi H, Ichiyama T, Shiomi M (2007) Acute encephalopathy associated with influenza and other viral infections. Acta Neurol Scand Suppl 186:45-56

67. Tauber SC, Eiffert H, Brück W, Nau R (2017) Septic encephalopathy and septic encephalitis. Expert Rev Anti-Infect Ther 15(2): 121-132. https://doi.org/10.1080/14787210.2017.1265448

68. Young GB (2013) Encephalopathy of infection and systemic inflammation. J Clin Neurophysiol 30(5):454 461. https://doi.org/ 10.1097/WNP.0b013e3182a73d83

69. Dobbs MR (2011) Toxic encephalopathy. Semin Neurol 31(2): 184-193. https://doi.org/10.1055/s-0031-1277989

70. Guo YR, Cao QD, Hong ZS et al (2020) The origin, transmission and clinical therapies on coronavirus disease 2019 (COVID-19) outbreak - an update on the status. Mil Med Res 7(1):11. https:// doi.org/10.1186/s40779-020-00240-0

71. Mao L, Jin H, Wang M et al (2020) Neurologic manifestations of hospitalized patients with coronavirus disease 2019 in Wuhan, China. JAMA Neurol:e201127. https://doi.org/10.1001/ jamaneurol.2020.1127

72. Li YC, Bai WZ, Hashikawa T (2020) The neuroinvasive potential of SARS-CoV2 may play a role in the respiratory failure of COVID-19 patients [published online ahead of print, 2020 Feb 27]. J Med Virol. https://doi.org/10.1002/jmv.25728

73. Poyiadji N, Shahin G, Noujaim D, Stone M, Patel S, Griffith B (2020) COVID-19-associated acute hemorrhagic necrotizing encephalopathy: CT and MRI features. Radiology 296(2):E119E120. https://doi.org/10.1148/radiol.2020201187

74. Alsolami A, Shiley K (2017) Successful treatment of influenzaassociated acute necrotizing encephalitis in an adult using highdose oseltamivir and methylprednisolone: Case report and literature review. Open Forum Infect Dis 4(3):ofx145. https://doi.org/ $10.1093 /$ ofid/ofx 145

75. Baig AM (2020) Neurological manifestations in COVID-19 caused by SARS-CoV-2. CNS Neurosci Ther 26(5):499-501. https://doi.org/10.1111/cns.13372

76. Zanin L, Saraceno G, Panciani PP et al (2020) SARS-CoV-2 can induce brain and spine demyelinating lesions [published online ahead of print, 2020 May 4]. Acta Neurochir:1-4. https://doi. org/10.1007/s00701-020-04374-x
77. Chen T, Wu D, Chen H, Yan W, Yang D, Chen G, Ma K, Xu D et al (2020) Clinical characteristics of 113 deceased patients with coronavirus disease 2019: retrospective study. BMJ 368:m1091

78. Helms J, Kremer S, Merdji H, Clere-Jehl R, Schenck M, Kummerlen C, Collange O, Boulay C et al (2020) Neurologic features in severe SARS-CoV-2 infection. N Engl J Med 382(23):2268-2270. https://doi.org/10.1056/NEJMc2008597

79. Politi LS, Salsano E, Grimaldi M (2020) Magnetic resonance imaging alteration of the brain in a patient with coronavirus disease 2019 (COVID-19) and anosmia. JAMA Neurol 77(8):1028-1029

80. Abdel-Mannan O, Eyre M, Löbel U, Bamford A, Eltze C, Hameed B, Hemingway C, Hacohen Y (2020) Neurologic and radiographic findings associated with COVID-19 infection in children. JAMA Neurol 1:e202687

81. Reichard RR, Kashani KB, Boire NA, Constantopoulos E, Guo Y, Lucchinetti CF (2020) Neuropathology of COVID-19: a spectrum of vascular and acute disseminated encephalomyelitis (ADEM)like pathology. Acta Neuropathol 140(1):1-6

82. Vollono C, Rollo E, Romozzi M, Frisullo G, Servidei S, Borghetti A, Calabresi P (2020) Focal status epilepticus as unique clinical feature of COVID-19: a case report. Seizure. 78:109-112. https:// doi.org/10.1016/j.seizure.2020.04.009

83. Chougar L, Shor N, Weiss N, Galanaud D, Leclercq D, Mathon B, Belkacem S, Stroër S et al (2020) Retrospective observational study of brain magnetic resonance imaging findings in patients with acute SARS-CoV-2 infection and neurological manifestations. Radiology 17:202422

84. Radmanesh A, Raz E, Zan E, Derman A, Kaminetzky M (2020) Brain imaging use and findings in COVID-19: a single academic center experience in the epicenter of disease in the United States. AJNR Am J Neuroradiol 41(7):1179-1183

85. Dugue R, Cay-Martínez KC, Thakur KT, Garcia JA, Chauhan LV, Williams SH, Briese T, Jain K et al (2020) Neurologic manifestations in an infant with COVID-19. Neurology. 94(24):1100 1102

86. Helms J, Kremer S, Merdji H, Schenck M, Severac F, Clere-Jehl R, Studer A, Radosavljevic M et al (2020) Delirium and encephalopathy in severe COVID-19: a cohort analysis of ICU patients. Crit Care 24(1):491

87. Galougahi MK, Ghorbani J, Bakhshayeshkaram M, Naeini AS, Haseli S (2020) Olfactory bulb magnetic resonance imaging in SARS-CoV-2-induced anosmia: the first report. Acad Radiol 27(6):892-893

88. Scullen T, Keen J, Mathkour M, Dumont AS, Kahn L (2020) Coronavirus 2019 (COVID-19)-associated encephalopathies and cerebrovascular disease: the New Orleans Experience. World Neurosurg 141:e437-e446

89. Cabirac GF, Soike KF, Zhang JY et al (1994) Entry of coronavirus into primate CNS following peripheral infection. Microb Pathog 16(5):349-357. https://doi.org/10.1006/mpat.1994.1035

90. Gane SB, Kelly C, Hopkins C (2020) Isolated sudden onset anosmia in COVID-19 infection. A novel syndrome? Rhinology. 58(3):299-301. https://doi.org/10.4193/Rhin20.114

91. Aarli JA (1983) The immune system and the nervous system. J Neurol 229(3):137-154. https://doi.org/10.1007/BF00313738

92. Reinhold AK, Rittner HL (2017) Barrier function in the peripheral and central nervous system - a review. Pflugers Arch 469(1):123134. https://doi.org/10.1007/s00424-016-1920-8

93. Koyuncu OO, Hogue IB, Enquist LW (2013) Virus infections in the nervous system. Cell Host Microbe 13(4):379-393. https://doi. org/10.1016/j.chom.2013.03.010

94. Netland J, Meyerholz DK, Moore S, Cassell M, Perlman S (2008) Severe acute respiratory syndrome coronavirus infection causes neuronal death in the absence of encephalitis in mice transgenic for human ACE2. J Virol 82(15):7264-7275. https://doi.org/10. 1128/JVI.00737-08 
95. De Felice FG, Tovar-Moll F, Moll J, Munoz DP, Ferreira ST (2020) Severe acute respiratory syndrome coronavirus 2 (SARSCoV-2) and the central nervous system. Trends Neurosci 43(6): 355-357. https://doi.org/10.1016/j.tins.2020.04.004

96. Kiyatkin EA (2019) Respiratory depression and brain hypoxia induced by opioid drugs: morphine, oxycodone, heroin, and fentanyl. Neuropharmacology. 151:219-226. https://doi.org/10. 1016/j.neuropharm.2019.02.008

97. Fugate JE (2017) Anoxic-ischemic brain injury. Neurol Clin 35(4):601-611. https://doi.org/10.1016/j.ncl.2017.06.001

98. Pedroso JL, Barsottini OG, Espay AJ (2019) Movement disorders in metabolic disorders. Curr Neurol Neurosci Rep 19(2):7. Published 2019 Feb 9. https://doi.org/10.1007/s11910-019-09213

99. Kumar AJ, Motta-Teixeira LC, Takada SH et al (2019) Behavioral, cognitive and histological changes following neonatal anoxia: male and female rats' differences at adolescent age. Int J Dev Neurosci 73:50-58. https://doi.org/10.1016/j.ijdevneu. 2018.12.002

100. Ren L, Zhang W, Han P et al (2019) Influenza A virus (H1N1) triggers a hypoxic response by stabilizing hypoxia-inducible factor- $1 \alpha$ via inhibition of proteasome. Virology. 530:51-58. https:// doi.org/10.1016/j.virol.2019.02.010

101. Wang GL, Jiang BH, Rue EA, Semenza GL (1995) Hypoxiainducible factor 1 is a basic-helix-loop-helix-PAS heterodimer regulated by cellular O2 tension. Proc Natl Acad Sci U S A 92(12):5510-5514. https://doi.org/10.1073/pnas.92.12.5510

102. Iyer NV, Kotch LE, Agani F et al (1998) Cellular and developmental control of $\mathrm{O} 2$ homeostasis by hypoxia-inducible factor 1 alpha. Genes Dev 12(2):149-162. https://doi.org/10.1101/gad.12. 2.149

103. Duette G, Pereyra Gerber P, Rubione J et al (2018) Induction of HIF- $1 \alpha$ by HIV-1 infection in CD4+ T cells promotes viral replication and drives extracellular vesicle-mediated inflammation. mBio 9(5):e00757-e00718. Published 2018 Sep 11. https://doi. org/10.1128/mBio.00757-18

104. Mazzon M, Peters NE, Loenarz C et al (2013) A mechanism for induction of a hypoxic response by vaccinia virus. Proc Natl Acad Sci U S A 110(30):12444-12449. https://doi.org/10.1073/pnas. 1302140110

105. Lindahl SGE (2020) Using the prone position could help to combat the development of fast hypoxia in some patients with COVID-19 [published online ahead of print, 2020 Jun 2]. Acta Paediatr. https://doi.org/10.1111/apa.15382

106. Nagel MA, Mahalingam R, Cohrs RJ, Gilden D (2010) Virus vasculopathy and stroke: an under-recognized cause and treatment target. Infect Disord Drug Targets 10(2):105-111. https://doi.org/ $10.2174 / 187152610790963537$

107. Gilden DH, Kleinschmidt-DeMasters BK, Wellish M, HedleyWhyte ET, Rentier B, Mahalingam R (1996) Varicella zoster virus, a cause of waxing and waning vasculitis: the New England Journal of Medicine case 5-1995 revisited. Neurology. 47(6): 1441-1446. https://doi.org/10.1212/wnl.47.6.1441

108. Miller EC, Elkind MS (2016) Infection and stroke: an update on recent progress. Curr Neurol Neurosci Rep 16(1):2. https://doi. org/10.1007/s11910-015-0602-9

109. Klok FA, Kruip MJHA, van der Meer NJM et al (2020) Incidence of thrombotic complications in critically ill ICU patients with COVID-19. Thromb Res 191:145-147. https://doi.org/10.1016/j. thromres.2020.04.013

110. Poissy J, Goutay J, Caplan M et al (2020) Pulmonary embolism in COVID-19 patients: awareness of an increased prevalence [published online ahead of print, $2020 \mathrm{Apr} 24$ ]. Circulation. https://doi. org/10.1161/CIRCULATIONAHA.120.047430
111. Willyard C (2020) Coronavirus blood-clot mystery intensifies. Nature. 581(7808):250. https://doi.org/10.1038/d41586-02001403-8

112. Magro C, Mulvey JJ, Berlin D et al (2020) Complement associated microvascular injury and thrombosis in the pathogenesis of severe COVID-19 infection: a report of five cases [published online ahead of print, 2020 Apr 15]. Transl Res S19315244(20)30070-0. https://doi.org/10.1016/j.trsl.2020.04.007

113. Fogarty H, Townsend L, Ni Cheallaigh C et al (2020) More on COVID-19 coagulopathy in Caucasian patients [published online ahead of print, 2020 May 12]. Br J Haematol. https://doi.org/10. 1111/bjh.16791

114. Sohal S, Mossammat M (2020) COVID-19 presenting with seizures [published online ahead of print, 2020 May 1]. IDCases. 20: e00782. https://doi.org/10.1016/j.idcr.2020.e00782

115. Hepburn M, Mullaguri N, George P et al (2020) Acute symptomatic seizures in critically ill patients with COVID-19: is there an association? [published online ahead of print, 2020 May 28]. Neurocrit Care:1-5. https://doi.org/10.1007/s12028-020-01006-1

116. Vellozzi C, Iqbal S, Broder K (2014) Guillain-Barre syndrome, influenza, and influenza vaccination: the epidemiologic evidence. Clin Infect Dis 58(8):1149-1155. https://doi.org/10.1093/cid/ ciu005

117. Zhao H, Shen D, Zhou H, Liu J, Chen S (2020) Guillain-Barré syndrome associated with SARS-CoV-2 infection: causality or coincidence? Lancet Neurol 19(5):383-384. https://doi.org/10. 1016/S1474-4422(20)30109-5

118. Alberti P, Beretta S, Piatti M et al (2020) Guillain-Barré syndrome related to COVID-19 infection. Neurol Neuroimmunol Neuroinflamm 7(4):e741. Published 2020 Apr 29. https://doi. org/10.1212/NXI.0000000000000741

119. Camdessanche JP, Morel J, Pozzetto B, Paul S, Tholance Y, Botelho-Nevers E (2020) COVID-19 may induce Guillain-Barré syndrome. Rev Neurol (Paris) 176(6):516-518. https://doi.org/10. 1016/j.neurol.2020.04.003

120. Padroni M, Mastrangelo V, Asioli GM et al (2020) Guillain-Barré syndrome following COVID-19: new infection, old complication? [published online ahead of print, 2020 Apr 24]. J Neurol:1-3. https://doi.org/10.1007/s00415-020-09849-6

121. El Otmani H, El Moutawakil B, Rafai MA et al (2020) COVID-19 and Guillain-Barré syndrome: more than a coincidence! Rev Neurol (Paris) 176(6):518-519. https://doi.org/10.1016/j.neurol. 2020.04.007

122. Virani A, Rabold E, Hanson T et al (2020) Guillain-Barré Syndrome associated with SARS-CoV-2 infection [published online ahead of print, $2020 \mathrm{Apr} 18]$. IDCases 20:e00771. https://doi. org/10.1016/j.idcr.2020.e00771

123. Abu-Rumeileh S, Abdelhak A, Foschi M, Tumani H, Otto M (2020) Guillain-Barré syndrome spectrum associated with COVID-19: an up-to-date systematic review of 73 cases. J Neurol 25:1-38

124. Joob B, Wiwanitkit V (2020) COVID-19 can present with a rash and be mistaken for dengue. J Am Acad Dermatol 82(5):e177

125. Jang H, Boltz D, Sturm-Ramirez K, Shepherd KR, Jiao Y, Webster R, Smeyne RJ (2009) Highly pathogenic H5N1 influenza virus can enter the central nervous system and induce neuroinflammation and neurodegeneration. Proc Natl Acad Sci U S A 106:14063-14068

126. Doty RL (2008) The olfactory vector hypothesis of neurodegenerative disease: is it viable? Ann Neurol 63:7-15

127. Potter MR, Chen JH, Lobban NS, Doty RL (2020) Olfactory dysfunction from acute upper respiratory infections: relationship to season of onset. Int Forum Allergy Rhinol 6:706-712. https:// doi.org/10.1002/alr.22551 
128. Suzuki M, Saito K, Min WP, Vladau C, Toida K, Itoh H, Murakami S (2007) Identification of viruses in patients with postviral olfactory dysfunction. Laryngoscope 117:272-277

129. van Riel D, Verdijk R, Kuiken T (2015) The olfactory nerve: a shortcut for influenza and other viral diseases into the central nervous system. J Pathol 235:277-287

130. Lechien JR, Chiesa-Estomba CM, De Siati DR, Horoi M, Le Bon SD, Rodriguez A, Dequanter D, Blecic S et al (2020) Olfactory and gustatory dysfunctions as a clinical presentation of mild-tomoderate forms of the coronavirus disease (COVID-19): a multicenter European study. Eur Arch Otorhinolaryngol 277(8):22512261. https://doi.org/10.1007/s00405-020-05965-1

131. Beltran-Corbellini A, Chico-Garcia JL, Martinez-Poles J, Rodriguez-Jorge F, Natera-Villalba E, Gomez-Corral J, GomezLopez A, Monreal E et al (2020) Acute-onset smell and taste disorders in the context of COVID-19: a pilot multicenter PCRbased case-control study. Eur J Neurol. https://doi.org/10.1111/ ene. 14273

132. Vaira LA, Salzano G, Petrocelli M, Deiana G, Salzano FA, De Riu G (2020) Validation of a self-administered olfactory and gustatory test for the remotely evaluation of COVID-19 patients in home quarantine [published online ahead of print, 2020 may 1]. Head Neck. https://doi.org/10.1002/hed.26228

133. Colizzi M, Bortoletto R, Silvestri M, Mondini F, Puttini E, Cainelli C, Gaudino R, Ruggeri M et al (2020) Medically unexplained symptoms in the times of COVID-19 pandemic: a case report. Brain Behav Immun Health 5:100073

134. Yifan T, Ying L, Chunhong G, Jing S, Rong W, Zhenyu L, Zejuan G, Peihung L (2020) Symptom cluster of ICU nurses treating COVID-19 pneumonia patients in Wuhan, China. J Pain Symptom Manag 60(1):e48-e53

135. Barello S, Palamenghi L, Graffigna G (2020) Burnout, and somatic symptoms among frontline healthcare professionals at the peak of the Italian COVID-19 pandemic. Psychiatry Res 290:113129

136. Goularte JF, Serafim SD, Colombo R, Hogg B, Caldieraro MA, Rosa AR (2020) COVID-19 and mental health in Brazil: psychiatric symptoms in the general population. J Psychiatr Res 132:3237

137. Naskar C, Grover S, Sharma A (2020) Telephonic survey and psychological aid for patients with somatic symptom disorders for the impact of lockdown and COVID-19 pandemic. Int J Soc Psychiatry 29:20764020954247

138. Ottestad W, Seim M, Mæhlen JO (2020) COVID-19 with silent hypoxemia. Tidsskr Nor Laegeforen 140(7)

139. Tobin MJ, Laghi F, Jubran A (2020) Why COVID-19 silent hypoxemia is baffling to physicians. Am J Respir Crit Care Med 202(3):356-360

140. Couzin-Frankel J (2020) The mystery of the pandemic's 'happy hypoxia'. Science 368:455-456

141. Banzett RB, Lansing RW, Evans KC, Shea SA (1996) Stimulusresponsecharacteristics of $\mathrm{CO} 2$-induced air hunger in normal subjects. RespirPhysiol 103:19-31

142. Nouri-Vaskeh M, Sharifi A, Khalili N, Zand R, Sharifi A (2020) Dyspneic and non-dyspneic (silent) hypoxemia in COVID-19: possible neurological mechanism. Clin Neurol Neurosurg 198: 106217

143. Lu Y, Li X, Geng D, Mei N, Wu PY, Huang CC, Jia T, Zhao Y et al (2020) Cerebral micro-structural changes in COVID-19 patients-an MRI-based 3-month follow-up study. EClinicalMedicine. 25:100484

144. Li YC, Bai WZ, Hirano N, Hayashida T, Hashikawa T (2012) Coronavirus infection of rat dorsal root ganglia: ultrastructural characterization of viral replication, transfer, and the early response of satellite cells. Virus Res 163:628-635

145. Andries K, Pensaert MB (1980) Immunofluorescence studies on the pathogenesis of hemagglutinating encephalomyelitis virus infection in pigs after oronasal inoculation. Am J Vet Res 41(9): 1372-1378

146. Matsuda K, Park CH, Sunden Y et al (2004) The vagus nerve is one route of transneural invasion for intranasally inoculated influenza a virus in mice. Vet Pathol 41:101-107

147. Chasey D, Alexander DJ (1976) Morphogenesis of avian infectious bronchitis virus in primary chick kidney cells. Arch Virol 52: 101-111

148. Kramer T, Enquist LW (2013) Directional spread of alphaherpesviruses in the nervous system. Viruses 5(2):678-707

149. Maximova OA, Bernbaum JG, Pletnev AG (2016) West Nile virus spreads transsynaptically within the pathways of motor control: anatomical and ultrastructural mapping of neuronal virus infection in the primate central nervous system. PLoS Negl Trop Dis 10(9): e0004980

150. Li K, Wohlford-Lenane C, Perlman S et al (2016) Middle East respiratory syndrome coronavirus causes multiple organ damage and lethal disease in mice transgenic for human dipeptidyl peptidase 4. J Infect Dis 213:712-722

151. Ugolini G, Kuypers HG, Strick PL (1989) Transneuronal transfer of herpes virus from peripheral nerves to cortex and brainstem. Science 243(4887):89-91

152. Doll JR, Thompson RL, Sawtell NM (2019) Infectious herpes simplex virus in the brain stem is correlated with reactivation in the trigeminal ganglia. J Virol 93(8):e02209-e02218

153. Tirawatnpong S, Hemachudha T, Manutsathit S, Shuangshoti S, Phanthumchinda K, Phanuphak P (1989) Regional distribution of rabies viral antigen in central nervous system of human encephalitic and paralytic rabies. J Neurol Sci 92(1):91-99

154. Kalia M, Mesulam MM (1980) Brain stem projections of sensory and motor components of the vagus complex in the cat: II. Laryngeal, tracheobronchial, pulmonary, cardiac, and gastrointestinal branches. J Comp Neurol 193:467-508

155. McCray PB Jr, Pewe L, Wohlford-Lenane C et al (2007) Lethal infection of K18-hACE2 mice infected with severe acute respiratory syndrome coronavirus. J Virol 81:813-821

156. Hadziefendic S, Haxhiu MA (1999) CNS innervation of vagal preganglionic neurons controlling peripheral airways: a transneuronal labeling study using pseudorabies virus. J Auton Nerv Syst 76:135-145

157. Petko B, Tadi P (2020) Neuroanatomy, nucleus Ambiguus. In: StatPearls. StatPearls Publishing, Treasure Island

158. Zhang SY, Clark NE, Freije CA et al (2018) Inborn errors of RNA lariat metabolism in humans with brainstem viral infection. Cell 172(5):952-965.e18

159. Telias I, Katira BH, Brochard L (2020) Is the prone position helpful during spontaneous breathing in patients with COVID-19? [published online ahead of print, 2020 May 15]. JAMA. https:// doi.org/10.1001/jama.2020.8539

160. Manganelli F, Vargas M, Iovino A, Iacovazzo C, Santoro L, Servillo G (2020) Brainstem involvement and respiratory failure in COVID-19. Neurol Sci 41(7):1663-1665

161. Román GC, Spencer PS, Reis J, Buguet A, Faris M, Katrak SM, Láinez M, Medina MT et al (2020) The neurology of COVID-19 revisited: a proposal from the environmental neurology specialty Group of the World Federation of Neurology to implement international neurological registries. J Neurol Sci 414:116884. https:// doi.org/10.1016/j.jns.2020.116884

162. Benameur K, Agarwal A, Auld SC, Butters MP, Webster AS, Ozturk T, Howell JC, Bassit LC et al (2020) Encephalopathy and encephalitis associated with cerebrospinal fluid cytokine alterations and coronavirus disease, Atlanta, Georgia, USA. Emerg Infect Dis 1. https://doi.org/10.3201/eid2609.202122

163. Zhou L, Zhang M, Gao J, Wang J (2020) Sars-Cov-2: underestimated damage to the nervous system [published online 
ahead of print, 2020 Mar 24]. Travel Med Infect Dis:101642. https://doi.org/10.1016/j.tmaid.2020.101642

164. Smith JC, Ellenberger HH, Ballanyi K, Richter DW, Feldman JL (1991) Pre-Bötzinger complex: a brainstem region that may generate respiratory rhythm in mammals. Science 254(5032):726729. https://doi.org/10.1126/science. 1683005

165. Barrett KE, Barman SM, Brooks HL, Yuan JX-J (2019) Ganong's review of medical physiology, 26th edn. McGraw-Hill Education, New York

166. Hoffmann M, Kleine-Weber H, Schroeder S, Krüger N, Herrler T, Erichsen $\mathrm{S}$ et al (2020) SARS-CoV-2 cell entry depends on ACE2 and TMPRSS 2 and is blocked by a clinically proven protease inhibitor. Cell 181(2):271-280

167. Imai Y, Kuba K, Rao S et al (2005) Angiotensin-converting enzyme 2 protects from severe acute lung failure. Nature 436(7047): $112-116$

168. Keidar S, Kaplan M, Gamliel-Lazarovich A (2007) ACE2 of the heart: from angiotensin I to angiotensin (1-7). Cardiovasc Res 73: 463-469

169. Kuba K, Imai Y, Rao S et al (2005) A crucial role of angiotensin converting enzyme 2 (ACE2) in SARS coronavirus-induced lung injury. Nat Med 11(8):875-879

170. Talan J (2020) COVID-19: neurologists in Italy to colleagues in US: look for poorly-defined neurologic conditions in patients with the coronavirus. Neurol. Today. https://journals.lww.com/ neurotodayonline/blog/breakingnews/pages/post.aspx?PostID= 920

171. Ramani A, Müller L, Ostermann PN, Gabriel E, Abida-Islam P, Müller-Schiffmann A, Mariappan A, Goureau O et al (2020) SARS-CoV-2 targets cortical neurons of 3D human brain organoids and shows neurodegeneration-like effects. bioRxiv 2020.05.20.106575. https://doi.org/10.1101/2020.05.20.106575
172. Selvaraj V, Sacchetti D, Finn A, Dapaah-Afriyie K (2020) Acute vision loss in a patient with COVID-19. R I Med J (2013) 103(6): 37-38

173. Ding Q et al (2020) The clinical characteristics of pneumonia patients co-infected with 2019 novel coronavirus and influenza virus in Wuhan, China. J Med Virol

174. Xu XW, Wu XX, Jiang XG, Xu KJ, Ying LJ, Ma CL, Li SB, Wang HY et al (2020) Clinical findings in a group of patients infected with the 2019 novel coronavirus (SARS-Cov-2) outside of Wuhan, China: retrospective case series. BMJ 368:m606

175. Kotfis K, Williams Roberson S, Wilson JE, Dabrowski W, Pun BT, Ely EW (2020) COVID-19: ICU delirium management during SARS-CoV-2 pandemic. Crit Care 24(1):176. Published 2020 Apr 28. https://doi.org/10.1186/s13054-020-02882-x

176. Jin M, Tong Q (2020) Rhabdomyolysis as potential late complication associated with COVID-19 [published online ahead of print, 2020 Mar 20]. Emerg Infect Dis 26(7). https://doi.org/10. 3201/eid2607.200445

177. Wang D, Hu B, Hu C (2020) Clinical characteristics of 138 hospitalized patients with 2019 novel coronavirus-infected pneumonia in Wuhan, China. Jama. https://doi.org/10.1001/jama.2020. 1585 In press

178. Kirschenbaum D, Imbach LL, Ulrich S, Rushing EJ, Keller E, Reimann RR, Frauenknecht KBM, Lichtblau M et al (2020) Inflammatory olfactory neuropathy in two patients with COVID19. Lancet. 396(10245):166. https://doi.org/10.1016/S01406736(20)31525-7 Epub 2020 Jul 10

Publisher's Note Springer Nature remains neutral with regard to jurisdictional claims in published maps and institutional affiliations. 